\title{
Republican Strength at the Grass Roots: An Analysis at the County Level*
}

\author{
Charles S. Bullock III, University of Georgia
}

This paper analyzes growing Republicanism from the perspective of officeholding at the county level. Using data from a 1991 survey, we show that Republicans currently hold somewhat less than 10 percent of all county offices. Their greatest success has come in those posts offering a wider range of responsibilities. Republican county success is associated with the frequency of Republican majorities in statewide elections. Further, more Republican county officials are found in the Atlanta area, in counties experiencing more growth and, for some offices, in more affluent counties and those in which blacks constitute a higher proportion of the registered voters. The significance of the expanding corps of Republican officeholders is the potential for a more experienced cadre of candidates for higher offices than typically put forward in the past.

Today, despite numerous and, in places, extensive breaches in the once Solid South, arguably the least hospitable state to the GOP has been Georgia. ${ }^{1}$ As evidence, consider the following: the Peach State did not vote for a Republican presidential candidate for almost for 100 years until 1964 -- only Arkansas waited longer. No Republican won a statewide election until Mack Mattingly defeated Herman Talmadge for the U.S. Senate in 1980, and subsequently no Republican has won a state post. Georgia and Mississippi remain the last states not to have elected a Republican governor in this century. Georgia has never had more than two Republicans in its U.S. House delegation. No other southern state has had so small a proportion of its congressional seats held by the GOP, with Democrats always filling at least eight of the ten U.S. House seats. As recently as 1978, the congressional delegation was wholly Demcractic.

Joseph Aistrup (1989), who has studied Republican party organization at the local level, found Georgia's consistently to be the weakest. And while ten southern states supported Jimmy Carter in 1976, only his home state stood with him when he sought re-election. Georgia's resistance to Republicanism makes it an interesting -- albeit particularly inhospitable -- environment in which to examine the gradual emergence of two-party competition. The conditions associated with the spread of Republicanism in Georgia may well be associated with GOP development in other states where Democrats have proven to be less entrenched.

This paper assesses Republican development in terms of officeholding at the county level. Through a census of county election officials, we gathered information on partisan officeholding in early 1991 . These data update earlier research into party control of offices for the 1980s. Political and socioeconomic variables are explored in an effort to explain variance in the degree of Republican

*I appreciate the support of the Carl Vinson Institute of the University of Georgia and the work of Keith Gaddie who helped in the preparation of this article. 
strength in the ranks of county officialdom.

Much research into the emergence of the Republican party in the South has concentrated on partisan vote shares in presidential elections. This was a reasonable focus, for it was at the presidential level that most early gains were made by the GOP. If, however, the GOP is to become a significant player in the region's politics, it must develop more than a presidential presence. In every southern state, there have been successes in selected congressional and state legislative contests. In seven southern states Republicans have composed at least half of the U.S. House delegations at one time or another. Currently, Republicans hold a majority of Florida's congressional seats and four of eight in Louisiana. The GOP has been less potent in state legislatures, and the party has yet to achieve a majority anywhere in the South; but that breakthrough is possible as early as 1992, when redistricting reshapes legislative districts.

Republican control of congressional and state legislative seats has often been impeded by a paucity of qualified candidates. To have a pool of experienced candidates, Republicans need a grass roots organization, by which we mean not simply a viable county organization but Republicans experienced as county officeholders. The smallness of county-level constituencies permits relatively inexpensive campaigns where candidates can nurture campaigning and fundraising skills largely outside of the media's glare. Survivors of county contests should be more competitive when seeking higher office. Republicans often have blown opportunities for higher offices by running candidates who, even if successful in other endeavors, were maladroit campaigners. The presence of Republican county officials, then, may be the party's potential for success at higher levels in the future, for as Scammon and Barnes $(1985,14)$ have observed, it is "further down the fight card [where] Republicans are doing less well, and this is where realignments are made."

Having indicated that this research focuses on county level officeholding, it should be made clear what it is not. Analyses of the partisan identification of voters and how subsets of voters have either embraced the GOP, or remained firm in their commitments to the Democratic party, are beyond the scope of this paper.

\section{Potential Correlates of Republican Officeholding}

Initial Republican gains in Georgia, as in the rest of the South, came in presidential elections. Since 1964, the state has voted Democratic in presidential elections only when a native son was the nominee. The presidential coattails of Barry Goldwater in 1964 elected Georgia's first Republican member of the U.S. House in this century. It is reasonable to anticipate, therefore, that Republican success in county offices is related to GOP strength at the top of the ticket. To explore this possibility, shares of the counties' vote going to Republican presidential candidates beginning in 1980 will be examined as possible correlates of Republican county officeholding. 
The GOP in Georgia is notorious for failing to translate support for its presidential nominees into success elsewhere on the ballot. Many voters supported Democrats for other offices while giving landslide majorities to Republican presidential nominees in 1972, 1984, and 1988. Since presidential support overstates Republican strength, the share of the vote won by Republicans for various state offices will also be examined. Included are the last two open-seat contests for governor (1982 and 1990), the 1980 senatorial election in which Mack Mattingly ended Herman Talmadge's Senate career, and the election six years later which unseated Mattingly. Also examined is a Public Service Commission contest from 1988 and the Insurance Commissioner election of 1990. We ignore what appear to be throwaway candidacies such as opponents to Senator Sam Nunn in 1984 and Governor Joe Frank Harris in 1986. Neither challenger polled as much as $30 \%$ of the vote, and Nunn's challenger was, in fact, denied assistance by the National Republican Senate Committee, at Mack Mattingly's request.

Republican candidates were successful in the 1984 and 1988 presidential elections and the 1980 Senate contest. Democratic Senator Wyche Fowler narrowly defeated Mattingly in 1986 and Republican Billy Lovett almost won the open Insurance Commissioner contest. In the other elections, the Democrat won handily. Counties in which Democrats won most of the nine contests are expected to be ones in which Republicans will have done poorly in county contests, if there is a linkage between statewide voting and local electoral success. Conversely, counties in which Republicans have won seven or more of the nine elections are expected to have high proportions of their local offices filled by Republicans.

Local Democratic candidates provide less attractive targets for Republicans than Walter Mondale or Michael Dukakis. Consequently Republicans seeking county offices can only infrequently count on rejection of their Democratic opponent as too liberal. Similarly, Republicans running statewide in Georgia have not succeeded in sticking the liberal label on their opponents (cf., Brownstein 1986). Consequently, voting patterns for Republicans in state contests may prove a better predictor of GOP county officeholding than support for Republican presidential candidates.

Since short-term electoral influences may render any single election an imperfect measure of partisan strength, we will explore the predictive powers of composite measures which combine multiple elections. Party registration is not an alternative measure of party strength in Georgia since there is no registration by party.

GOP strength in the South springs from a growing middle class (Black and Black 1987). In an attempt to capture a middle class orientation, median white income and median white education are used. Unfortunately, data from the 1990 Census are not yet available forcing us to rely on decade-old data.

Most of the middle class expansion has been rooted in suburbia (Cohen 1986). We will, therefore, explore several "blunt" measures of suburbanization. One is a dichotomous variable for the 18-county Atlanta metropolitan statistical 
area (MSA) and a second one distinguishes between metropolitan and nonmetropolitan counties throughout the state. A third variable distinguishes between more progressive and growing north Georgia versus the atrophying south.

In recent years, no group in America has been more loyal to the Democratic party than blacks. Not only have blacks provided wholehearted support for Democratic presidential candidates, they also provided the margin of victory for Governor Zell Miller and Democratic Insurance Commissioner Tim Ryles in 1990 and for Democratic Senator Wyche Fowler in 1986. On the assumption that blacks' ties to the Democractic party extend down to the local level, we expect that Republicans will hold fewer offices in counties with concentrations of blacks. Potential black political strength will be assumed both in terms of the percent black in the population and the percent black among registered voters.

While the black population was once predominantly rural, the number of majority black counties in farming areas has been declining for decades. Half of Georgia's ten largest cities, but only 17 rural counties, had more blacks than whites in 1990. While we expect that heavily black counties will elect Democrats, we also expect that metropolitan counties will elect Republicans. To take account of counties which, like Fulton, are urban and heavily black, an interaction term which combines these two variables will be examined.

Population growth is often associated with in-migration which may be pro-Republican (Phillips 1969; Wolfinger and Hagen 1985; Black and Black 1987; Stanley 1987). Counties undergoing rapid growth during the 1980s experienced an influx of whites and these new residents generally have weaker ties to the traditional Democratic party structure and leadership in the county. If they moved in from outside the region, they may have brought their Republican affiliation with them. We expect, then, that counties which had substantial increases in population from 1980 to 1990 will elect more Republicans. ${ }^{2}$

Legislative redistricting to create heavily black single-member districts (SMDs) often produces other overwhelmingly white districts more favorable to Republicans (Brace, Grofman and Handley 1987; Bullock and Gaddie 1991). We will explore whether Republicans do better in countywide offices, such as sheriff and tax commissioner, which are elected at-large (AL) as opposed to collegial bodies. Within collegial bodies such as school boards and county commissions, we will see whether Republicans hold a larger share of the seats under SMD than under at-large (AL) arrangements.

If we are correct in expecting that Republican strength is concentrated in metropolitan areas, then the use of SMDs in rural areas may not be associated with Republican officeholding. Rather, it is possible that use of SMDs in heavily Republican counties may provide one refuge for outnumbered Democrats who would be less likely to elect one of their own at-large. To test that proposition, we use an interaction term which combines use of SMDs with location in the Atlanta MSA. 


\section{Dependent Variables}

The four dependent variables include the proportion Republican on the county commission, the percentage Republican on the board of education (BOE), the percent GOP among administrative officials, and the share of Republicans in all elected county offices.

Every Georgia county has at least one county commissioner with the maximum number being ten. (Georgia is the only state which has solo county commissioners, an arrangement once widespread but gradually disappearing). Commissions with three to seven members are most common. While every county has a school board, not all are elected. Since our interest is in partisan electoral success, the analysis of school boards will be restricted to those counties which elect BOEs. ${ }^{3}$

There are a number of administrative officers in Georgia counties with every county electing a sheriff, probate judge, and clerk of court. Most counties also elect a tax commissioner, coroner, surveyor, and superintendent of schools. The range in the number of elected county officials is from 7 to 23 with the number for most counties being in the mid-teens.

Many counties (111) currently have no elected Republican while there are six counties with at least 10 Republican officeholders. Four of these are in metro Atlanta, another is the center of an urban area, and the sixth is in the mountains, an area of traditional Republican strength.

With the 1990 election, suburban Gwinnett County became the first in the state to have only Republicans in public office. Balancing Gwinnett, which is in northeast metro Atlanta, is Cobb County on the northwest where 94 percent of the officeholders are Republican. A south metro county, Fayette, ranks third in Republican success with 75 percent of its officeholders belonging to the GOP. In three other counties most officeholders are Republican with one of these being just north of Cobb, another being a bedroom community for Augusta, and the final one a mountain county. Two additional Atlanta-area counties are between 40 and 50 percent Republican among their officeholders.

Every Atlanta MSA county has elected at least one Republican as have 27 of the 38 MSA counties statewide. In contrast, only 22 of 121 non-MSA counties had Republican officials in 1991.

Table 1 shows the current distribution of Republican officeholders with the GOP most successful in winning county commissioners, 10 percent of whom are Republicans. This figure has doubled since 1987 and almost tripled over the last decade. Republicans are also relatively more common in the ranks of school board members, sheriffs and surveyors. In the other five offices, they hold approximately 2.5 percent of the posts. Overall the GOP now accounts for 7 percent of the county officials.

Following the 1990 election, 33 counties had one or more Republicans on their commissions and five counties (four in metro Atlanta and one in suburban 
Table 1. Republican County Officeholding, 1991

\begin{tabular}{lccc}
\hline & Number & \multicolumn{2}{c}{ Republicans } \\
& Elected & Number & Percent \\
\hline County Commission & 720 & 74 & 10.3 \\
School Board & 785 & 65 & 8.3 \\
Sheriff & 159 & 12 & 7.5 \\
Clerk of Court & 159 & 5 & 3.1 \\
Probate Judge & 159 & 4 & 2.5 \\
Corner & 152 & 4 & 2.6 \\
Superintendent of Education & 123 & 3 & 6.4 \\
Surveyor & 89 & 6 & 2.5 \\
Tax Commissioner & 157 & 4 & 7.1 \\
TOTAL & & & \\
\end{tabular}

Augusta) had no Democrats. Five other counties, three of which were in metro Atlanta, had Republican majorities. Another nine counties had at least a third of their seats in Republican hands. As with the totality of officeholders, Republican commissioners were concentrated in urban areas. All but one Atlanta MSA county had a Republican commissioner as did six of the 20 metro counties outside of the Atlanta area. The most dramatic gain in the 1990 election occurred in Cherokee County in the northern Atlanta MSA. Cherokee had a sole commissioner (Democrat) until the 1990 election, when it went to five seats which were swept by the GOP.

Republicans also held all school board seats in three Atlanta-area counties and were a majority in two other Atlanta counties. Republicans held at least half of the seats on eight boards of education. Overall, there are 28 counties having at least one Republican on the school board. These include ten Atlanta counties and four counties in other MSAs. In part, Republicans are less numerous on school boards for the same reason that Democrats are less numerous on school boards than on county commissions: in 37 counties, the post is nonpartisan.

Single administrators are also concentrated in the Atlanta MSA, where 21 of the 38 serving in 1991 are to be found. A second concentration is in the mountain counties, an area of traditional Republican strength dating back to the Civil War, and from which 11 current administrators come. Only 21 counties have elected Republican administrators, and 12 of these are in metro Atlanta.

An inspection of Republican officeholding on an election-by-election basis reveals that most gains have accompanied presidential elections. To illustrate, consider the post of commissioner, where Republicans have had the most success. Their proportion of seats went from 3.9 to 5.0 percent following the 1984 election and from 5.0 to 9.3 percent following the 1988 election. From 1981 to 1983 , and from 1985 to 1987 , there were no gains. The one percentage point increase from 1989 to 1991, while modest, is larger than in other non-presidential years. 
It should be noted that many Georgia counties stagger the terms of commissioners and board of education members and not all of the single administrators need to be elected in a single year. Thus, gains in presidential years are concentrated in less than the full set of offices.

\section{Correlates for Republican Officeholding}

Table 2 presents the correlation coefficients for our measures of Republican officeholding. The table is divided into two sections; the top portion reports political correlates while the lower portion provides socioeconomic correlates.

Table 2. Correlates of GOP Officeholding

\begin{tabular}{|c|c|c|c|c|}
\hline & $\begin{array}{l}\text { Total } \\
\text { Offices }\end{array}$ & Commission & $\begin{array}{l}\text { School } \\
\text { Board }\end{array}$ & $\begin{array}{l}\text { Single } \\
\text { Offices }\end{array}$ \\
\hline \multicolumn{5}{|l|}{ Political } \\
\hline Reagan 1980 & .57 & .55 & .57 & .46 \\
\hline Mattingly 1980 & .64 & .60 & .64 & .51 \\
\hline GOP 1980 & .66 & .62 & .65 & .52 \\
\hline Bell 1982 & .62 & .57 & .67 & .50 \\
\hline Reagan 1984 & .51 & .51 & .51 & .40 \\
\hline Mattingly 1986 & .50 & .51 & .51 & .35 \\
\hline Bush 1988 & .44 & .45 & .46 & .31 \\
\hline Brittingham 1988 & .73 & .72 & .68 & .57 \\
\hline GOP 1988 & .66 & .65 & .63 & .50 \\
\hline Isakson 1990 & .43 & .43 & .47 & .31 \\
\hline Lovett 1990 & .56 & .55 & .55 & .43 \\
\hline GOP 1990 & .54 & .54 & .57 & .41 \\
\hline GOP $1980-90$ & .68 & .66 & .68 & .53 \\
\hline GOPPOWER & .71 & .71 & .66 & .59 \\
\hline SMD (office) & - & .38 & .21 & - \\
\hline SMD (office)* ATLMSA & - & .53 & .25 & - \\
\hline Black Registration (\%) & -.35 & -.31 & -.32 & -.34 \\
\hline Black Registration* MSA & .14 & .18 & .11 & .16 \\
\hline \multicolumn{5}{|l|}{ Socioeconomic } \\
\hline Med White Education & .25 & .23 & .23 & .21 \\
\hline Med White Income (log) & .60 & .58 & .59 & .60 \\
\hline$M S A$ & .45 & .52 & .41 & .30 \\
\hline ATL MSA & .58 & .64 & .53 & .45 \\
\hline North Georgia & .29 & .28 & .24 & .25 \\
\hline Black Population & -.34 & -.29 & -.32 & -.33 \\
\hline Black VAP & -.34 & -.29 & -.31 & -.33 \\
\hline 1990 Population (log) & .52 & .49 & .59 & .53 \\
\hline 1980-90 Population Change & .57 & .55 & .56 & .45 \\
\hline
\end{tabular}


The array of coefficients shows most of the variables to be related to the measures of Republican county officeholding. Among the political variables, the share of the vote won by Brittingham in the 1988 Public Service Commission contest often has the strongest relationship with the dependent variables, ranging from .57 to .73 . Other strong correlates are the vote for Mack Mattingly in 1980 (range of .51 to .64) and the unsuccessful, 1982 gubernatorial campaign of Bob Bell (range of .50 to .67). The weakest correlations come from the election of George Bush in 1988 and the unsuccessful 1990 gubernatorial campaign of Johnny Isakson. Even the weakest of the electoral correlates are generally at least $r=.4$. Interestingly, despite the linkage between gains in GOP county officeholding and presidential elections, Table 2 shows stronger relationships between non-presidential vote shares and the dependent variables.

It is clear from Table 2 that current Republican county officeholding is not consistently tied to the more recent elections. One 1990 election (Isakson) has among the weakest correlates while the other 1990 election (Lovett for Public Service Commission) is moderately strong. The disparity is even greater for 1988 , with the correlation for the Brittingham election always being greater than for Bush.

Presidential elections, which opened the way for Republican growth in the South, were never among the strongest correlates and, except for Reagan in 1980, were relatively weak. The strength registered by Reagan in 1984 and Bush in 1988 is less directly linked to GOP victories in county offices than are some less successful Republican ventures. The strongest single correlate, the Brittingham vote, involved a relatively weak showing by a Republican candidate. Brittingham received 43 percent of the vote statewide and carried only 13 of the 159 counties. Of the elections considered, the only Republicans weaker than Brittingham were Reagan in 1980 (42 percent of the vote) and Bell, who lost the governorship in 1982 with 37 percent. The campaigns of Reagan in 1984 and Bush four years later attracted numerous Democrats who continued to vote for their own party's nominees for county offices.

Since two elections were included for 1980, 1988 and 1990, respectively, we averaged the vote in two elections and used that figure as a correlate. Table 2 shows that for 1980 , the coefficient for the combined figure is similar to the Mattingly vote taken by itself and is a better correlate than the Reagan vote. The GOP vote for 1988 is a stronger correlate than the Bush vote but slightly weaker than the Brittingham vote. The average Republican vote in 1990 is about as strong a correlate as the Lovett vote and somewhat better than the Isakson vote. Finally, when all nine elections are averaged and that figure is used, the bivariate coefficients are quite similar to the Brittingham vote, the single best election.

Table 3 lends strong support to our expectation that success in statewide campaigns will be linked to local victories. No Republicans serve in the 18 
counties in which Democrats swept all nine statewide contests examined. In counties in which Democrats won at least seven of the nine contests, the average share of offices held by Republicans never reaches three percent. Even when Republicans win four of the elections, they generally average less than 10 percent of the county posts. Only where Republicans led in seven statewide elections do they dominate some county offices, holding 83 percent of the commission seats. While they fill less than half of the administrative and board of education posts, overall they control half of the offices. In the four counties in which statewide Republicans trailed in no more than one election, the GOP is in command across the board. Among the strongest correlations reported in Table 2 are those for GOPPOWER, the number of times GOP efforts won majorities in a county.

Table 3. Average Share of Offices Filled by Republicans in 1991, Controlling for the Number of Statewide GOP Wins in the County, 1980-90

\begin{tabular}{cccrrr}
\hline $\begin{array}{c}\text { Number of } \\
\text { GOP Wins }\end{array}$ & All Offices & Commission & BOE & Single & N \\
\hline 0 & 0 & 0 & 0 & 0 & 18 \\
1 & 1.7 & 1.6 & 2.1 & 0 & 9 \\
2 & 1.1 & 1.3 & 1.9 & 0.5 & 60 \\
3 & 6.1 & 6.6 & 7.9 & 2.0 & 32 \\
4 & 5.8 & 10.1 & 7.4 & 1.0 & 15 \\
5 & 12.2 & 25.0 & 18.8 & 6.2 & 12 \\
6 & 17.7 & 83.3 & 12.1 & 16.1 & 4 \\
7 & 50.1 & 95.0 & 39.0 & 32.7 & 4 \\
8 or 9 & 79.0 & 85.7 & 63.4 & 4 \\
\hline
\end{tabular}

The number of counties totals 158 since one county slots all officials in non-partisan elections.

While Table 3 demonstrates a relationship between winning statewide elections and success at the local level, electing local Republicans lags behind victories for higher offices. Even when statewide campaigns are succeeding twothirds of the time, local Republicans are winning one-fourth of the time or less. Winning one-third of the statewide contests coincides with Democratic control of, on average, more than 90 percent of the local offices and virtually all of the administrative posts. Only when counties provide nearly uniform support for Republican candidacies are most administrative posts filled by Republicans. Since approximately 55 percent of the counties have voted for two or fewer of the Republican statewide candidates, the base for Democratic control of local offices is widespread and deep. Only eight counties fall into the two highest categories, those in which Republicans are elected to local office in substantial proportions.

As expected, Table 2 shows that the black percentage of a county's registrants correlated negatively with each measure of Republican officeholding. This relationship can account for approximately 10 percent of the variance. An interaction term which combines black registration with being located in an MSA 
is, however, quite weak.

For the two collegial bodies, the presence of single-member districts for the office in question was considered as a possible predictor. The relationship between share of the county commission seats elected from SMDs and percent Republican on the commission is .38, while the proportion of board of education offices from single-member districts shows less relationship to the presence of Republican board members $(r=.21)$. When the proportion of seats in singlemember districts is interacted with the dummy variable for a part of metro Atlanta, the coefficients increase but only slightly for BOEs.

\section{Socioeconomic Correlates}

Among the strongest correlates of Republican success in county offices is median white income. In this analysis the income figure has been logged to reduce the effect of outliers. This variable can explain approximately a third of the variance. It is a much stronger correlate than median white education (but see Aistrup 1989, 20).

A second strong correlate is the dummy variable for the Atlanta MSA, which is approximately as strong as the income measure and performs better than the dummy for all MSA counties in the state. A third strong correlate is the 1990 population figure, which also has been logged. A fourth potentially useful predictor is the change in a county's population during the 1980s. Correlates for the 1990 black population and voting age population are similar to those for black registration.

As expected, the bivariate relationships indicate that Republicans are more likely to win county offices in counties which have higher incomes, have larger populations, have experienced more population growth, and are located in the Atlanta area. These variables are interrelated although the correlations between the Atlanta MSA and the other two variables are approximately $\mathrm{r}=.5$. The strongest relationship is between income and population, at $\mathrm{r}=.66$.

\section{Multivariate Analysis}

Multivariate regression was used to determine which of the predictors contributed most to our understanding of Republican county officeholding. ${ }^{4}$ From Table 2 we see that all of the candidate variables are positively related to GOP officeholding. Further, the composite measures are among the strongest correlates, so these will be examined as predictors in place of individual elections.

One possibility is the average vote share for the Republican candidates reported in Table 2. A potential problem with using the average figure is a threshold phenomenon associated with Republican county officeholding. There are no Republican officeholders in any county in which the average percent of the vote for Republican statewide candidates is below 33, and only three counties in 
which Republicans averaged 40 percent or less of the vote have Republican county officials. The relationship, then, is roughly linear from about 40 percent of the average vote up, but below that point, the relationship is flat. A possible approach to this distribution is a growth curve which can be modeled using the natural log of the mean GOP vote.

Another potential predictor is the number of times that the county cast a majority of its votes for the nine Republican candidates, the measure used in Table 3 . Table 3 indicates that the long tail to the left found using the mean vote figure does not exist for the number of GOP majorities. Moreover, the number of majorities in statewide contests registered in the county (GOPPOWER) is among the strongest bivariate correlates.

In addition to a measure of GOP strength in the electorate, the dummy variable for counties in the Atlanta MSA was a strong correlate (ATLMSA). A third predictor is the change in population from 1980 to 1990 (POPCHANG), which the bivariate analysis suggested would be a useful predictor. The proportion of blacks among registered voters (PCTBLREG) is also included in the models even though it did not have a particularly strong bivariate relationship. Nonetheless, given the degree of support which black voters have given Democratic candidates, there are theoretical justifications for including this variable.

Finally, the $\log$ of median white income is strongly related to Republican officeholding and will be considered. A second set of equations will be estimated including income, since including this measure eliminates approximately 20 counties from the analysis due to missing data.

Models were estimated using each of the three measures of Republican strength. The average percentage of the vote for Republican candidates and the $\log$ of that measure produced similar results. A somewhat better fit was achieved using the number of GOP majorities in statewide contests (GOPPOWER) as the independent variable and it is the results of those efforts which are reported in Tables 4 and 5. The share of the variance explained is, with one exception (Republicans on school boards) in Table 4, larger using GOPPOWER than for either measure of average Republican support.

The models in Table 4 reveal that for the total set of offices as well as for the three subsets, the strongest relationship exists between the strength shown in Republican statewide candidacies and Republican county officialdom. The slope for GOPPOWER when regressed on all offices is .051, meaning that each additional majority rolled up by a statewide Republican translates into approximately one more county office for the GOP. The slopes for individual offices indicate that two majorities in statewide contests translate into an additional Republican on a seven-member commission or board of education, ceterus paribus.

Republicans do consistently better in counties which experienced greater population increases during the 1980s. Only for single, administrative offices was POPCHANG not twice as large as its standard error, while Republicans tend to do 
especially well on BOEs in growing counties. ${ }^{5}$ The third predictor indicates that for each office analyzed, Republicans are more likely in the Atlanta MSA than elsewhere. Being in the Atlanta area is associated with roughly one additional Republican commissioner on a five-person board and two additional Republicans on a seven-member body. Further, Atlanta MSA counties tend to have 13 percent more Republicans when all offices are considered and about ten percent more Republicans on school boards and in administrative posts.

Table 4. Four Variable Models of Republican County Officeholding

\begin{tabular}{|c|c|c|c|c|}
\hline & $\begin{array}{l}\text { All } \\
\text { Offices }\end{array}$ & Commission & BOEs & $\begin{array}{l}\text { Single } \\
\text { Offices }\end{array}$ \\
\hline Intercept & -.141 & -.196 & -.147 & -.104 \\
\hline GOPPOWER & $\begin{array}{c}.051 \\
(.006) \\
{[.570]}\end{array}$ & $\begin{array}{c}.068 \\
(.008) \\
{[.566]}\end{array}$ & $\begin{array}{c}.056 \\
(.009) \\
{[.507]}\end{array}$ & $\begin{array}{c}.038 \\
(.007) \\
{[.486]}\end{array}$ \\
\hline POPCHANG & $\begin{array}{l}.155 \\
(.046) \\
{[.218]}\end{array}$ & $\begin{array}{l}.150 \\
(.059) \\
{[.158]}\end{array}$ & $\begin{array}{r}.217 \\
(.068) \\
{[.266]}\end{array}$ & $\begin{array}{r}.090 \\
(.051) \\
{[.147]}\end{array}$ \\
\hline ATLMSA & $\begin{array}{c}.130 \\
(.031) \\
{[.249]}\end{array}$ & $\begin{array}{c}.242 \\
(.039) \\
{[.348]}\end{array}$ & $\begin{array}{c}.100 \\
(.051) \\
{[.157]}\end{array}$ & $\begin{array}{r}.080 \\
(.034) \\
{[.177]}\end{array}$ \\
\hline PCTBLREG & $\begin{array}{c}.154 \\
(.062) \\
{[.157]}\end{array}$ & $\begin{array}{c}.231 \\
(.080) \\
{[.176]}\end{array}$ & $\begin{array}{c}.154 \\
(.096) \\
{[.127]}\end{array}$ & $\begin{array}{r}.089 \\
(.068) \\
{[.105]}\end{array}$ \\
\hline $\begin{array}{l}\mathrm{N} \\
\mathrm{R}^{2} \\
\text { Adj. } \mathrm{R}^{2}\end{array}$ & $\begin{array}{r}158 \\
.62 \\
.61\end{array}$ & $\begin{array}{r}158 \\
.65 \\
.65\end{array}$ & $\begin{array}{r}123 \\
.53 \\
.51\end{array}$ & $\begin{array}{r}158 \\
.39 \\
.38\end{array}$ \\
\hline
\end{tabular}

Standard errors in parentheses; standardized coefficients in brackets.

The fourth variable indicates Republicans do better where blacks constitute a larger share of the registrants, although the relationship is weak for BOEs and single offices. This relationship is contrary to the direction suggested by theory and shown in the bivariate relationships. Once other factors are held constant, higher black registration is associated with more Republican officials. Since we have no reason to believe that blacks are voting Republican in local contests, the success of GOP county candidates in areas with more black voters must result from Republicans doing especially well among white voters, which in turn may stem from racial policy differences. Surveys show that black and white southerners differ on key political evaluations. Black and Black $(1987,67)$ have noted the existence of "a deep ideological split by race within the southern working class 
." Working class whites (by narrow margins) and middle class whites (by substantial margins) reject many of the policy proposals favored by blacks. Since blacks are such an important element in the Democratic party, counties in which blacks are more concentrated may nominate relatively liberal Democrats. Liberal Democrats at the local level may confront the same problems that liberal Democrats running for president have experienced in Georgia and in the South generally: liberal nominees for local office may stampede whites to the GOP (cf. Barnes 1990; Wolfinger and Hagen 1985, 13).

The modeling efforts in Table 4 were most successful for all offices and for commissions. All predictors were strongly related to these two dependent variables and almost two-thirds of the variance was explained. The model is least successful for single offices, where only GOPPOWER and ATLMSA were statistically significant. The relative success of the model across offices is probably related to the degree of variation in the dependent variable. As has been previously noted, more counties are all-Democratic in single offices than for other posts.

When models were re-estimated to include median white income (WHINC), the new variable was positively related to all four measures of Republican officeholding, but did not achieve statistical significance for commissions or single offices (see Table 5). Furthermore, the inclusion of white income and the consequent exclusion of some counties resulted in the percent black among registrants ceasing to be statistically significant. For boards of education, GOPPOWER and WHINC were the only variables having coefficients twice the size of their standard errors, although ATLMSA just missed that standard. Including median white income increased the adjusted $\mathrm{R}^{2} \mathrm{~S}$ for each dependent variable, although the increase for commissions was negligible.

In any case, in all eight models tested, the measure of Republican strength in statewide elections invariably is the strongest correlate of GOP success at the county level. Counties in the Atlanta area are also more likely to elect Republicans to county office. There is a tendency for Republicans to serve more often in counties which have grown and some tendency for them to be found more often in counties having relatively high levels of black registration. Finally, the GOP has done better overall and on school boards in more affluent counties. With the exception of the positive relationship between PCTBLREG and Republican officeholding, all of the relationships are in the anticipated direction. The statistical significance frequently observed for demographic variables in explaining Republican county officeholding is at variance with Aistrup's (1989) conclusion that demographic variables had little effect in explaining the development of the GOP in state Senate districts. 
Republican Strength

Table 5. Five Variable Models of Republican County Officeholding

\begin{tabular}{|c|c|c|c|c|}
\hline & $\begin{array}{l}\text { All } \\
\text { Offices }\end{array}$ & Commission & BOEs & $\begin{array}{l}\text { Single } \\
\text { Offices }\end{array}$ \\
\hline Intercept & -.263 & -.291 & -.331 & -.185 \\
\hline GOPPOWER & $\begin{array}{c}.043 \\
(.006) \\
{[.471]}\end{array}$ & $\begin{array}{c}.058 \\
(.009) \\
{[.469]}\end{array}$ & $\begin{array}{c}.048 \\
(.010) \\
{[.431]}\end{array}$ & $\begin{array}{c}.027 \\
(.007) \\
{[.377]}\end{array}$ \\
\hline POPCHANG & $\begin{array}{l}.121 \\
(.050) \\
{[.167]}\end{array}$ & $\begin{array}{l}.157 \\
(.069) \\
{[.159]}\end{array}$ & $\begin{array}{l}.133 \\
(.076) \\
{[.156]}\end{array}$ & $\begin{array}{c}.189 \\
(.052) \\
{[.154]}\end{array}$ \\
\hline ATLMSA & $\begin{array}{c}.125 \\
(.031) \\
{[.248]}\end{array}$ & $\begin{array}{c}.220 \\
(.043) \\
{[.320]}\end{array}$ & $\begin{array}{c}.100 \\
(.053) \\
{[.155]}\end{array}$ & $\begin{array}{c}.092 \\
(.033) \\
{[.226]}\end{array}$ \\
\hline PCTBLREG & $\begin{array}{c}.123 \\
(.066) \\
{[.115]}\end{array}$ & $\begin{array}{l}.168 \\
(.090) \\
{[.115]}\end{array}$ & $\begin{array}{c}.101 \\
(.099) \\
{[.078]}\end{array}$ & $\begin{array}{c}.099 \\
(.068) \\
{[.115]}\end{array}$ \\
\hline WHINC & $\begin{array}{l}.0010 \\
(.0004) \\
{[.180]}\end{array}$ & $\begin{array}{l}.0009 \\
(.0006) \\
{[.118]}\end{array}$ & $\begin{array}{l}.0016 \\
(.0007) \\
{[.217]}\end{array}$ & $\begin{array}{l}.0007 \\
(.0004) \\
{[.142]}\end{array}$ \\
\hline $\begin{array}{l}\mathrm{N} \\
\mathrm{R}^{2} \\
\text { Adj. } \mathrm{R}^{2}\end{array}$ & $\begin{array}{r}139 \\
.68 \\
.67\end{array}$ & $\begin{array}{r}139 \\
.68 \\
.67\end{array}$ & $\begin{array}{r}112 \\
.60 \\
.58\end{array}$ & $\begin{array}{r}139 \\
.47 \\
45\end{array}$ \\
\hline
\end{tabular}

Standard errors in parentheses; standardized coefficients in brackets.

\section{Conclusions}

Many Georgia counties continue to be bastions of one-party domination. In 111 counties, no Republicans currently hold public office. In 18 of these counties, no Republican -- not even Reagan in 1984 or Bush in 1988 -- won a majority from 1980 to 1990 . There are 18 counties which would be exclusively Democratic in their leadership structure but for a single Republican. At the other extreme, one county has only Republican officeholders and a second county has a single remaining Democrat. These are both counties in which all nine statewide Republican campaigns succeeded. Simple arithmetic reveals that in only 28 of the state's 159 counties is there anything more than token representation of both parties in the ranks of officials and this is using a minimal threshold for tokenism.

The persistence of Democratic control is particularly stark in the administrative posts held by a single official. As shown in Table 1, Republicans remain 
largely excluded from posts such as sheriff, clerk of court and probate judge. At least two possible explanations exist for the continued Democratic control of these positions. First, since these offices have, by definition, a countywide constituency, they may be more difficult to win than seats on collegial bodies which are increasingly chosen from single-member districts. Second, since many of the responsibilities for the single-official offices are largely administrative, they may less often attract the politically ambitious. No doubt a review of most local newspapers would demonstrate that far more attention is devoted to school board and county commission activities than to the operation of the office of the clerk of court or the responsibilities of the coroner. Therefore, elected administrators may rarely be challenged, as individuals interested in shaping public policy and/ or a political career gravitate toward the collegial bodies.

In only four counties do Republicans hold at least half of the administrative posts and two of these are, of course, counties in which they fill more than 90 percent of all offices. Republicans hold a larger share of the administrative posts than of all offices in eight counties, but in only three counties is the difference as much as 10 percentage points. It appears, then, that Republicans turn their attention to administrative posts after they have had some success on a county's collegial bodies.

The broader responsibilities of the county commission may explain why this post has the highest proportion of Republicans. Similarly, the sheriff's responsibilities may explain why more Republicans hold this office than any other administrative post. The one figure in Table 1 not consonant with an explanation linking significance of the office to the presence of Republicans is for surveyors, where $6.7 \%$ Republicans is surprisingly high.

Officeholding in most Georgia counties remains a one-party affair, and in these one-party counties, the Democrats continue their traditional sway. While a review of the distribution of the vote in statewide candidacies or consideration of the growing share of county offices held by Republicans hints at emerging twoparty competition, a more accurate assessment might be that while a second party is emerging in Georgia, the two parties are compartmentalized. There are vast areas which are safely Democratic except in presidential elections. A few counties are the domain of the GOP. In less than one-third of the state's counties -- and with a more demanding standard it might be as few as one-sixth of the counties -- is competition discernible in the distribution of county offices.

To the extent that the past provides guidance for the future, we should anticipate that Republican statewide candidates will do better. Unless there are major changes such as an economic debacle, Republicans in Georgia have a lock on the presidential vote. While most white Georgians' first flirtation with the GOP came in a presidential election, for many the relationship has ripened from a onenight stand to matrimony. Well-funded, highly visible Republican candidates running statewide regularly attract a majority of the white vote. Even Republicans who are neither well-endowed financially nor well-known now garner 40 to 50 
percent of the white vote in contests for down-ticket statewide offices.

The disparity between Republican success in presidential and even in other statewide contests and their share of county offices results, in part, from the distribution of the state's population across its many counties. The GOP rarely wins county posts in the numerous sparsely populated, rural counties which account for an inordinate number of county officials. Counties far from the Atlanta MSA and which stagnated or lost population during the 1980s remain the bulwark of Democratic strength. There are few signs on the horizon to indicate a change for these counties. A second factor, particularly important in understanding the failure of the GOP to win state offices, is that the massive support given Democratic candidates by blacks means majority white support for a Republican is insufficient. Republicans need about 60 percent of the white vote to win. Republican shares in the white electorate are creeping up but state candidates, other than Mattingly in 1980 , continue to come up short.

Prospects for increasing the number of Republican county officials are more cautious than for gains at other levels. In two counties Republican officeholding has "maxed out." There are other urban counties in which maximum feasible Republican officeholding will be less than 100 percent since if there is a compartmentalized black or lower income white population, Democrats will continue to be elected from certain school board and county commission singlemember districts. Therefore it should not be assumed that with suburbanization, Republicans will invariably win all of a county's offices. Further, suburbs do not attract exclusively up-scale whites. Already some Atlanta metro counties are experiencing black in-migration and these new black residents provide strong support for Democratic candidates. The 1990 elections saw the GOP advance into one south Atlanta county stopped, as Democrats regained some posts -- including that of school superintendent -- which had been lost in previous elections. Thus while Republicans will control additional posts in outlying metro Atlanta counties, and in counties adjacent to other MSAs, there is a finite limit to the likely growth of the GOP unless Republicans make further converts among white voters, particularly among the less affluent and less educated who have displayed greater Democratic loyalties. ${ }^{6}$

The Republican party seems destined to govern suburban counties, and those areas house a rising share of the population. However, in the absence of extensive county consolidation, which is highly improbable, the meetings of Georgia county commissioners, school board members, and probate judges will continue to be predominantly gatherings of Democrats.

While it is unlikely that Republicans can control most county offices in Georgia (in the absence of unprecedented partisan realignment in the electorate), their expansion into the ranks of county officialdom in urban counties may portend substantial rewards. County officials may constitute a "farm team" which will provide the GOP with experienced campaigners for the growing number of state legislative and congressional posts potentially within their grasp. From the ranks 
of county officials could come the personnel necessary to make the GOP competitive in the Georgia General Assembly, where it currently holds 20 percent of the seats. ${ }^{7}$ After a term in the legislature, Republicans with county officeholding experience may be more competitive in elections for Congress and statewide office than were most of the candidates put forward by the GOP in the past. While Republicans boasted in 1990 of fielding candidates (all unsuccessful) for each of Georgia's ten congressional seats for the first time, only one challenger to the nine Democratic incumbents had experience as an officeholder. Further, while Republicans have often done credibly in campaigns for the Public Service Commission, these individuals have been political novices. If campaigns at the county level become a proving ground for ambitious Republicans, then even though Republican officials remain restricted to urbanizing and mountain counties, the party may ultimately win other offices by running a more politically savvy set of elites.

A pool of county officials might also provide a larger number of challengers, thereby reducing the many positions currently won by Democrats without partisan competition. One likely explanation for the slower growth of the GOP in Georgia than in most other southern states is its failure to contest numerous positions. When there is no Republican alternative, it is impossible for the GOP to win even if late in the campaign embarrassing information about the Democratic nominee becomes known. Further, voters have less incentive to affiliate with a party which fields a limited slate. Providing a full range of Republican candidates would doubtless attract more voters to the GOP. Some of these voters would identify with the party, thereby heightening the likelihood that they would consistently vote Republican.

In Georgia, as in most of the South, the initial gains made by the GOP were generated by presidential candidates. The trickle down of support from presidential campaigns has produced some gains, but has not made the GOP a consistent winner of congressional or statewide offices in any southern state. Nor has the GOP captured a majority in any southern legislative chamber. The Achilles' heel of the GOP has been weakness at the grass roots. In the growth areas of Georgia and elsewhere, the GOP has demonstrated varying levels of strength, and in the most affluent and most rapidly growing counties it has become the majority party, controlling elections from the court house to the White House. Swelling ranks of county officeholders may provide the experience, personnel and organization needed for the GOP to become fully competitive with the Democratic party in the South.

\section{Broader Relevance of the Southern Experience}

The slowness with which bipartisan competition has developed in Georgia and much of the South suggests that opposing parties of roughly equal strength will only gradually take root in nations which have histories of one-party 
rule. Consider the more daunting obstacles confronted by proponents of bipartisan competition in Eastern Europe and the Third World. Unlike the Eastern European countries which for decades had only the monolithic Communist Party, the southern states had histories of bifactional or multifactional competition (Key 1949; Black and Black 1987) and experience in recruiting and grooming candidates, raising campaign funds, and conducting campaigns, which were easily transferred to GOP insurgents in some states. Indeed, some Republican leaders, such as Senator Strom Thurmon, were converted Democrats. Voters and even elites in the Eastern bloc and in many developing countries have had little experience in a politically competitive environment. It seems reasonable to hypothesize that it will take longer to develop stable partisan competitiveness in systems in which even factional competition is alien.

While organized partisan opposition as we know it in the United States or Great Britain may be slow to develop, the crumbling of one-party governments may result in a multitude of splinter parties with coalitions of different parties dominant at various levels of governing. Both coalition partners and, indeed, the very parties themselves, may change radically from election to election.

Particularly positive for nation building would be the emergence of broad-based parties resting on coalitions containing diverse elements of society. If, however, party lines reinforced ethnic or tribal divisions in ethnically-diverse nations, parties may make governing more difficult. The nature of the support for parties, of course, depends in large part on the kinds of appeals made by party leaders. In the South, for example, some white politicians, such as Republican Senator Jesse Helms, have made appeals designed to attract whites but few blacks. Alternatively, many Democratic candidates in the South, and even some Republicans such as Arkansas Governor Winthrop Rockefeller have won substantial black support when opposing Democrats who embraced policy options at variance with black preferences. In recent years ethnically divisive appeals have become much less successful in the South (Black 1976).

The American South is still in the process of making more partisanly competitive what had traditionally been a one-party system. The experience of the South may provide lessons for other nations involved in a similar transformation. There are, of course, differences -- such as the extensive factionalism which frequently characterized the hegemonic Democratic party -- that are quite unlike the intolerance for opposition displayed by communist parties or even some revolutionary parties in the Third World. The purpose here is not to argue that the southern experience is a model for nations in other parts of the world, but that it is an experience worth sharing for the insights it provides into one path toward the proliferation of grassroots challenges to single party dominance.

\section{NOTES}

${ }^{1}$ The Almanac of American Politics would take issue with this statement for it 
sees Arkansas as the southern state most likely to vote for Democratic presidential nominees (Barone and Ujifusa 1989, p. 57). Blair and Savage (1988) also see Arkansas as the southern state most resistant to GOP in-roads.

${ }^{2}$ Georgia's big growth counties during the 1980s are heavily white while those experiencing the most precipitous declines often have sizable black populations.

${ }^{3} \mathrm{~A}$ constitutional amendment requiring that all school boards be elected and that all superintendents be appointed was introduced in the 1991 session of the Georgia General Assembly. That arrangement is found in many counties but elsewhere both the superintendent and the school board are elected while in two counties both the board and the superintendent are appointed.

${ }^{4} \mathrm{~A}$ number of possible models were examined. Those presented here were selected in the interests of parsimony and avoiding collinearity.

${ }^{5}$ Since a number of Georgia school districts choose their board members in nonpartisan elections, models for the proportion Republican on school boards were reestimated using only the number of partisan posts as the denominator in calculating percent Republican. The results for these models were very similar to those reported in Tables 4 and 5 .

${ }^{6}$ The South Carolina GOP is far more advanced than Georgia's, having a lineage of statewide officeholding going back to Strom Thurmond's post Goldwater conversion. Republicans have won three of South Carolina's last five gubernatorial elections and have claimed as many as four of the six congressional seats. Currently a third of the state House belongs to the GOP as do two statewide executive officers (secretary of state and superintendent of education). Despite these successes, which far surpass the Georgia experience, Palmetto Republicans continue to encounter rejection in many county elections. South Carolina may provide a model for Georgia's partisan evolution.

${ }^{7}$ With the decennial redistricting, additional opportunities will be presented to the GOP as suburban areas take legislative seats from rural, south Georgia. State legislative posts, unlike county offices, will be increasingly concentrated in suburbia.

\section{REFERENCES}

Aistrup, Joseph A. 1989. Top-Down Republican Party Development in the South: A Test of Schlesinger's Theory. Paper presented at the annual meeting of the Midwest Political_Science Association, Chicago, IL.

Barnes, James A. 1990. Liberal Trend Pleases GOP in the South:National Journal 22 (July 7): $1672-1673$.

Barone, Michael and Grant Ujifusa. 1989. The Almanac of American Politics 1990. Washington, DC: National Journal.

Black, Earl. 1976. Southern Governors and Civil Rights. Cambridge: Harvard University Press.

Black, Earl and Merle Black. 1987. Politics and Society in the South. Boston: Harvard University Press.

Blair, Diane D. and Robert L. Savage. 1988. The Appearances of Realignment and Dealignment in Arkansas. In Robert H. Swansborough and David M. Brodsky, eds., The South's New Politics. Columbia: University of South Carolina Press. 


\section{Republican Strength}

Brace, Kimball, Bernard Grofman and Lisa Handley. 1987. Does Redistricting Aimed to Help Blacks Necessarily Help Republicans? Journal of Politics 49:169-185.

Brownstein, Ronald. 1986. Still No Breakthrough. National Journal 18 (September 20): 2228-2232.

Bullock, Charles S. III and Ronald Keith Gaddie. 1991. Changing From Multi-Member to Single-Member Districts. Paper presented at the annual meeting of the Midwest Political Science Association, Chicago, IL, April 18-20.

Cohen, Richard E. 1986. A Subsurface Change. National Journal 18 (September 20): 2222-2226.

Jacobson, Gary C. and Samuel Kernell. 1981. Strategy and Choice in Congressional Elections. New Haven: Yale University Press.

Phillips, Kevin P. 1969. The Emerging Republican Majority. New Rochelle, NY: Arlington House.

Scammon, Richard and James A. Barnes. 1985. Republican Prospects: Southern Discomfort. Public Opinion 8 (October-November): 14-17.

Schlesinger, Joseph A. 1985. The New American Political Party. American Political Science Review 70: 1152-1169.

Stanley, Harold W. 1989. Southern Partisan Changes: Dealignment, Realignment, or Both. Journal of Politics 50: 64-88.

Vedlitz, Arnold, James A. Dyer and David B. Hill. 1988. The Changing Texas Voter. In Robert H. Swansborough and David M. Brodsky, eds., The South's New Politics. Columbia: University of South Carolina Press.

Wolfinger, Ray and Michael G. Hagen. 1985. Republican Prospects: Southern Comfort. Public Opinion 8 (October-November): 8-13. 